\title{
Apontamentos à análise da reforma militar na transição espanhola ${ }^{1}$
}

Suzeley Kalil MATHIAS ${ }^{\bullet}$

\begin{abstract}
Resumo: Neste texto, revisitamos o processo político espanhol recente, enfatizando as questões relativas às Forças Armadas (FFAA), buscando compreender desde a formação destas Forças antes da ditadura de Francisco Franco, passando por esta e chegando aos dias de hoje, quando parece que as reformas promovidas ao longo dos últimos 30 anos, resultaram na incorporação definitiva das FFAA à democracia.
\end{abstract}

Palavras-chave: Democracia; Forças Armadas; América do Sul; Governo.

\section{Introdução}

A transição dos regimes autoritários de base militar para governos democráticos e a reconstrução da democracia supõe a reintegração dos setores castrenses à nova realidade, com sua subordinação à autoridade civil. No estudo destes processos, a análise desenvolvida por O'Donnell e Schmitter (1988) tornou-se um paradigma. Baseando-se no regime burocrático-autoritário (RBA) do qual se pretende transitar, os casos concretos podem ser classificados entre dois pólos. Em um dos pólos, estão as transições totalmente negociadas, enquanto no outro estão as

- Livre Docente pela Universidade Estadual Paulista (UNESP). Professora do Departamento de Educação, Ciências Sociais e Política Internacional e do Programa de Pós-graduação em História Faculdade de História, Direito e Serviço Social - Campus de Franca 14409-160 - Franca - SP - Brasil. Pesquisadora do Grupo de Estudos de Defesa e Segurança Internacional (GEDES). E-mail: suzeley@uol.com.br 
transições por colapso do RBA. A Espanha viveu a transição do RBA que serviu de ponto de partida para a criação do modelo de transições negociadas, pois foi um caso de transição para a democracia bem sucedida em subordinar e, mais importante, em integrar as Forças Armadas (FFAA) ao regime democrático, o que justifica tomar o caso espanhol como base para responder "Como se consegue reformar as FFAA de forma a torná-las eficientes e integradas ao regime democrático?" E, subsidiariamente, "como avaliar o papel da educação militar neste processo?

A integração das FFAA ao regime pós-autoritário implica no exercício da autoridade civil e também na compreensão da necessidade de proporcionar uma nova formação às FFAA, o que aponta para a educação militar enquanto elemento fundamental neste processo, pois é por meio da educação que, não apenas incorporam-se os valores da disciplina e hierarquia próprios da conduta castrense, mas também se introduzem elementos necessários à constituição de FFAA inteiramente comprometidas com o regime democrático. É neste sentido que tomamos aqui a educação como uma variável estratégica.

Compreender a educação como variável estratégica é atribuir-lhe, ainda que potencialmente, o dissenso como parte intrínseca. Pensar estrategicamente é pensar em relação a um conflito que se nos configura como futuro possível. Não significa preparação para a guerra, mas para enfrentar esse conflito e resolvê-lo, que pode ser pela forma de solução não beligerante (Saint-Pierre \& Mathias, 2004: 2). A formulação estratégia acontece no âmbito da decisão política do Estado e é por essa razão que a educação militar é aqui tomada como variável estratégica, pois

distintamente de outras áreas das políticas públicas, a Educação é uma variável privilegiada, pois, mais que uma política da área social de qualquer governo, é um assunto que transcende os limites da administração pública, sendo uma das primeiras áreas a sofrer com as mudanças seja no governo seja nos regimes políticos. Esta condição de área sensível - porque entendida 
APONTAMENTOS À ANÁLISE DA REFORMA MILITAR...

como veículo de difusão de idéias e, portanto, de formação de consciências e de treinamento para responder a determinadas demandas do mundo do trabalho e da cidadania - faz dela uma variável extremamente importante para analisar as possibilidades de autonomia ou não de um país ou região (...). Deste ponto de vista, analisar a educação como variável estratégica significa pensá-la como disponibilidade para atingir os objetivos definidos pela política (Id. Ib.).

Outro princípio que rege este trabalho é que a educação é uma variável estratégica que se faz presente particularmente nos momentos transicionais e, principalmente, quando já estão sob o manto da democracia porque se localiza um dissenso forte entre o meio castrense e o meio civil, o que vem à tona mais rapidamente em regimes abertos do que nos RBAs. Em outras palavras, se a educação militar era uma disponibilidade no RBA porque estava em sintonia relativamente à doutrina do próprio governo, na democracia a educação militar, se permanece como estava, pode vir a ser não apenas um problema para a estabilidade interna, mas também uma vulnerabilidade frente a outros Estados.

Entende-se também que para a transformação de sujeitos em cidadãos, nenhum ator político deverá ser discriminado, para o bem ou para o mal e, portanto, a educação militar também é um meio de trazer a democracia para o Estado, incorporando sua burocracia como conjunto de agentes que tomam somente as liberdades democráticas como mecanismo de alargar seus direitos sociais e respeitar os direitos de todos os agentes, inclusive o direito de reivindicar.

Em outras palavras, para que a democracia ganhe consistência, ultrapassando seus limites formais eleitorais, é preciso que os valores democráticos, particularmente a tolerância relativamente aos diferentes e a aceitação do dissenso como parte das disputas políticas na democracia, seja introjetado como parte essencial da cidadania. É necessário que todos os atores sejam encarados como cidadãos, cujo direito de reivindicar, se manifestar e se opor à situação vigente é parte 
intrínseca do processo de cidadania. Se há vários atores que não estão preparados para assumir tais valores, porque os militares, que são educados para obedecer e não divergir, estariam? É isso que justifica enfatizar a educação como estratégica para a construção da democracia, pois é por meio dela, em particular por sua manifestação formal, o ensino, que se pode reformar o individuo e, no caso específico, o militar.

Neste texto, passaremos em revista a realidade política espanhola no processo de construção das FFAA ao longo do século XX, enfatizando as relações entre a instituição e a política desde a ditadura franquista até a governo Zapatero. Ao longo da discussão, perceber-se-á que a (re)construção da democracia ao longo dos últimos 40 anos foi facilitada pela frustração de projetos maximalistas e pela consolidação de ganhos mínimos, porém gerais, ainda que não equânimes, pelo conjunto da sociedade espanhola. Pode-se, portanto, dizer que a democracia no país ibérico está consolidada, pois soube negociar com o povo e com os atores que estavam no poder, em especial as FFAA, a construção de um regime democrático.

Para atingir os objetivos colocados, dividimos o texto em cinco partes que passam em revista o processo de constituição e reforma das FFAA na Espanha ao longo do século XX e início do século XXI. Na primeira parte, tratamos, em linhas muito gerais, do processo de formação das FFAA até a tomada do poder pelo general Francisco Franco. Na seqüencia, revisamos a forma de atuação militar sob o franquismo, enfatizando como as FFAA foram marcadas pela tarefa de manutenção da ordem interna. Depois, já na terceira parte, discutimos o tratamento dispensado ao setor castrense ao longo da transição, período definido como intermediário entre a ditadura e a democracia, ressaltando as diferenças de percepção entre direita e esquerda relativamente ao tema central. No quarto item, dedicamo-nos à análise das reformas promovidas para integrar as FFAA ao regime democrático e, por último, ressaltamos as reformas realizadas na educação militar, tema que temos como central para a compreensão não apenas da história espanhola recente, mas de como esta pode servir de base para a construção de um modelo 
APONTAMENTOS À ANÁLISE DA REFORMA MILITAR...

para o estudo de outros casos de transição entre regimes autoritários de base militar para governos e regimes democráticos.

Passado mais de 30 anos da morte de Francisco Franco, com vistas a enterrar definitivamente a experiência ditatorial e concomitantemente construir uma democracia sólida, com a plena subordinação das FFAA aos civis, esta experiência pode ser melhor analisada. Hoje, tem-se aquele distanciamento que permite ao estudioso relacionar eventos que apenas agora fazem sentido no todo. Na ocasião, muitos acontecimentos pareceram, aos olhos dos próprios agentes, como submissão aos interesses de uma certa elite, como a captulação diante do generalíssimo, que construíra, ao que tudo indicava, para a eternidade um lugar para a Espanha que não era o que realmente os espanhóis queriam.

\section{Militares na Espanha pré-franquista}

Em trabalhos anteriores, sempre insistimos na importância dos antecedentes para a análise das transições dos RBAs. Assim, para compreender como a transição da ditadura para a democracia na Espanha foi produto de pactos entre atores diversos, é necessário ao menos mencionar alguns fatores que constituem o cerne do processo político espanhol no século XX. Ademais, é preciso resgatar como se desenvolveu a relação entre militares e governo sob Franco.

Certamente, aqui não é o melhor lugar para tratar de tais assuntos. No entanto, correndo o risco da simplificação exacerbada, resumimos nas poucas linhas que se seguem o processo de formação da Espanha moderna, enfatizando a posição das FFAA neste processo.

São três os elementos que constrangem a formação do Estado espanhol ao longo de todo o século passado. O primeiro foi o de equacionar as diferentes regiões e suas escolhas políticas com um poder central que objetivava criar um Estado 
espanhol que congregasse todas as regiões até hoje conhecidas como território do país. Também a proximidade com a África, ao mesmo tempo que transformava o país em território estratégico para a Europa, representava o limite do país em se integrar ao velho continente. Por último, mas não menos importante, a perda de seu poder imperial, consumada no século XIX, foi determinante na formação do Estado.

Em relação à perda de seu império, sua hegemonia vinha sendo contestada pelos demais países europeus desde o tratado de Westfalia (1648), ${ }^{2}$ tendo sido confirmada ao longo das guerras napoleônicas por meio dos processos de independência da América Ibérica. Seu último suspiro resultou na hegemonia norte-americana sobre toda a região, do México à Patagônia, conseqüência da guerra de 1898 entre Espanha e EUA pelo domínio dos últimos territórios do império espanhol localizados no Caribe.

Relacionado com o primeiro e processado em paralelo, está a unificação da Espanha. No final do século XV, constitui-se o Estado espanhol pela centralização sob uma única coroa das diferentes nações ibéricas. Resultado de mais de dois séculos de guerras e acordos políticos, permitiu “... a primeira experiência moderna de dominação hegemônica sobre a Europa que, paralelamente, gerou os elementos de desintegração da monarquia espanhola..." (Garcés, 2008: 298), monarquia que afiançava a própria existência do Estado.

Geograficamente, a Espanha é um país chave na Europa, ${ }^{3}$ pois controla o único acesso ao Mar Mediterrâneo, sendo ainda o país mais próximo da África, da qual dista cerca de $12 \mathrm{Km}$. Tais características garantiram tanto o exercício de sua hegemonia na Europa na época das grandes navegações, quanto lhe abriu caminho para a expansão colonial. Herrero Fabregat confirma a importância estratégica da Andaluzia - território que se encontra ao sul da península ao qual pertence Gibraltar, estreito que abre a região para a Europa e América - ao informar que a região é "... o último reduto da defesa da Espanha de uma invasão do norte peninsular..." (2002: 126), ao que 
APONTAMENTOS À ANÁLISE DA REFORMA MILITAR...

acrescentamos que também o é para as ameaças vindas da África.

Em contrapartida, essa proximidade com a África fez com que a Europa Ocidental identificasse a Espanha como um território não europeu. Se esta visão no início foi alimentada porque a hegemonia do país ibérico era contestada, depois, já com Franco no poder, foi ainda mais exacerbada, pois a ditadura promoveu o fechamento do país, o que o empurrava para fora do continente. Segundo Sonia Alda, este elemento impulsionou sobremaneira a Espanha para a democracia, pois a abertura para a Europa era encarada como único caminho impeditivo à 'africanização' do país. ${ }^{4}$

Tendo em mente os fatores mencionados, que representam o pano de fundo do desenvolvimento histórico espanhol, é importante lembrar alguns fatos que marcaram a história do país ao longo do século XX e que condicionaram tanto a formação da ditadura franquista quanto a transição desta para a democracia. A simples menção de alguns desses acontecimentos explica o processo que culminou na forma adquirida pela transição desde a ditadura na Espanha.

É importante destacar que a monarquia constituía a própria unidade das nações ibéricas em torno do Estado espanhol. Ao longo do século XIX, a monarquia experimentou seu crescente desgaste e, ao mesmo tempo, os militares, apesar das derrotas para as forças coloniais, ganhavam legitimidade de intervenção política. Assim, foi a partir de diversos pronunciamientos que a monarquia deixou de ser absoluta e tornou-se liberal (1868), viveu um breve período republicano (1874-5), sendo seguido pela restauração dos Bourbons sob a forma de monarquia constitucional (1876), que entre instabilidades e colapsos, manteve-se no poder até 1931.

Desses mais de 50 anos, cabe destacar a ditadura instaurada pelo general Primo de Rivera, em 1923. No lugar da grande liberdade intelectual até então conhecida, a Espanha viveu os anos 20 sob a ditadura pessoal de Rivera, mas também experimentou desenvolvimento industrial, o crescimento das obras públicas e o equacionamento do problema militar. Porém, 
essa prosperidade foi ladeada pelo aumento da corrupção e da influência castrense na política, mostrando-se incapaz de vencer a forte depressão que se instaurou a partir de 1929.

A monarquia, libertando-se do ditador, ainda tentou manter-se no poder, mas não enfrentou eficientemente os problemas que então se colocavam, em especial a questão agrária na Andaluzia e o crescente nacionalismo na Catalunha e no País Vasco. Ao fracasso monárquico seguiu-se a organização da Segunda República, proclamada em abril de 1931.

Ainda em 1931, uma nova Constituição é escrita, que é entendida como "decididamente democrática e laica e potencialmente descentralizadora" (Jackson [1965], 2005: 60). No mesmo mês do nascimento da Carta Republicana, as eleições levam a esquerda ao poder à qual se segue um período de contestações anarquistas e ao golpe fracassado do general Sanjurjo (agosto de 1932). Novas eleições acontecem em 1933, desta vez a direita sai vitoriosa - a causa principal é atribuída aos mesmos anarquistas, pois promoveram a abstenção por meio do movimento "greve do voto" -, mas perdem as eleições de fevereiro de 1936, na qual as esquerdas chegam ao poder com uma pequena diferença de votos. Em junho do mesmo ano, as FFAA, lideradas pelo governador do Marrocos, ainda possessão espanhola, Francisco Franco, promovem o golpe contra a República a fim de restabelecer a ordem. Porém, não logram a vitória esperada, tendo que enfrentar a oposição em pelo menos um terço do território espanhol.

Percebe-se, pois, que a Segunda República não foi menos instável que a monarquia precedente. Embora tenha começado com mais ansiedade do que com fatos que corroborassem a insegurança, a polarização entre direita e esquerda aumentava dia a dia promovendo o caldo necessário ao golpe de 1936 que, ao não conseguir unificar a Espanha em torno de um projeto, levou à Guerra Civil.

Franco não era o líder inconteste do levante, mas representava a melhor opção contra a República, que formava o governo progressista de esquerda de então. Durante os três anos dos embates entre os nacionalistas (que congregava a 
APONTAMENTOS À ANÁLISE DA REFORMA MILITAR...

Falange, a Igreja, os monarquistas ou, em outras palavras, a direita) e os republicanos (de anarquistas a republicanos legalistas que defendiam o governo eleito em 1933), toda a Europa e os EUA debateram a situação espanhola e, por fim, mesmo o governo de Stalin, defendeu a legitimidade da liderança nacionalista, colocando suas forças em favor da constituição de um governo comandado pelo 'generalíssimo', como fora denominado Francisco Franco que liderara a vitória dos nacionalistas em 1939.

\section{Os militares sob Franco}

A ditadura então instaurada só fez aprofundar antiga tradição das FFAA de ocuparem-se da ordem interna, conforme acordo tácito entre elas e a burguesia, segundo o qual o Exército manteria sua autonomia e prerrogativas e, em troca, garantiria a ordem interna, em especial frente ao movimento operário (Serra, 2008: 127). O próprio Franco enfatiza esta realidade em discurso datado de meados dos 1950: "a missão sagrada das FFAA de uma nação é manter a ordem interna e é justamente esta [missão] que nós realizamos." (Apud Serra, ib., id., grifos nossos).

O regime político que a partir do final dos anos 1930 se desenvolveu era bastante semelhante ao que vigorava na Itália e Franco tinha laços relativamente estreitos com os nazistas. Entretanto, como se sabe, a Espanha manteve sua neutralidade ao longo da Segunda Guerra. Porém, a ditadura não poderia ser apoiada pelos aliados, que lutaram justamente para varrer da Europa regimes como aquele. Com isso, a política por eles adotada relativamente à Espanha foi a de isolar o país, o que apenas contribuiu para a consolidação do franquismo.

Mais que um novo regime político, o que Franco almejava era destruir por completo a experiência republicana e seus representantes na Guerra Civil. Tratando qualquer sinal de oposição com execuções sumárias, as bases do regime eram cada vez mais estreitas, o que reforçava e aumentava a presença 
das FFAA como necessárias à manutenção da ditadura. Nas palavras de uma estudiosa, "ao longo da ditadura, o Exército seria uma força continuamente reforçada e reestruturada para que pudesse ir adaptando-se às distintas circunstâncias, atuando como elemento de apoio essencial na defesa do sistema (...)" (Barrios, 2006: 17, grifos nossos).

Para garantir que as FFAA estivessem sempre ao seu lado, Franco militarizou ${ }^{5}$ paulatinamente o governo. O primeiro passo foi dividir o Ministério da Defesa em três partes, um para cada Força. Depois, distribuiu cargos em diferentes escalões do governo, sempre respeitando a hierarquia militar, isto é, a indicação para um cargo era orientada pela patente do militar de forma a jamais haver um general subordinado a um coronel, por exemplo. No ministério (primeiro escalão), chegou-se a ter seis militares: na Marinha, Exército, Força Aérea, Interior, Obras Públicas e na pasta da Indústria, este último ocupado por um general reformado (Id.: 23).

A militarização do governo não se resumiu a treinar os militares para o exercício de funções eminentemente civis ou em subordinar as políticas públicas aos anseios militares. Pelo contrário, por meio da somatória entre participação no governo e força mantenedora da ordem, esse processo forjou, e de maneira quase unânime, a crença que a essência do regime político espanhol é responsabilidade das FFAA. Como diria o ministro de Assuntos Exteriores, José Félix de Lequerica, em 1945,

Estamos dispostos a dar tudo o que temos para continuar no poder. Teremos que fazer sacrifícios, e o faremos sem vacilar. Se for necessário dissolver a Falange, a dissolveremos. Inclusive acabaremos com Franco se for necessário. O importante é preservar o fundamento do governo, seus membros não importam. O fundamento do governo é o Exército, assim como sua influência política para prevenir que caiamos na calamidade da democracia (Apud Garcés, 2006: 48).

Franco também buscava apoio na Igreja e para obtê-lo, à semelhança dos militares, atendia às reivindicações do clero 
APONTAMENTOS À ANÁLISE DA REFORMA MILITAR...

sempre que podia. Já nos primeiros momentos da ditadura, foi abolida toda a legislação que separava o Estado da Igreja, o que não significou, entretanto, que o generalíssimo se colocasse sob controle papal. Esta aproximação reforçou o caráter conservador das FFAA espanholas, modeladas desde sua criação pelo catolicismo, que era parte essencial dos currículos das Academias militares e exigência para a entrada na carreira (Serra, 2008: 128). O caráter religioso dos militares reforçava também a idéia de salvacionismo das FFAA, posto que tomavam a si próprias como o fundamento do Estado. Não por acaso, a facção mais à direita da Igreja apoiava e participava daquele governo, a Opus Dei.

Além do limite de qualquer ditadura, isto é, aquele determinado pela longevidade daquele que se assume como ditador, os mesmos recursos de consolidação do franquismo alimentavam os limites deste regime. Conforme mencionado, a unidade espanhola baseava-se na monarquia, em sua habilidade em mostrar-se representante de todas as nações da península ibérica e no respeito às características dessas mesmas nações. Isso tornava necessário tanto a participação das FFAA na repressão quanto na política. Também o isolamento do país, particularmente em relação aos países europeus, serviu tanto para a consolidação da ditadura quanto para sua superação.

No que concerne à monarquia, ainda que desde o princípio de seu governo Franco tenha prometido o retorno do rei, não mencionou nem qual seria este rei e muito menos quando um novo monarca voltaria ao poder. Em paralelo, o plano de nacionalização daquele governo envolvia a imposição de uma língua e uma religião oficial para todo o território espanhol, o que somente foi possível por meio de continuada repressão.

Relativamente ao isolamento do país, a aproximação com o governo norte-americano a partir de 1950 e a participação das FFAA espanholas nas guerras ao lado das do EUA, fornecia um modelo castrense moderno e funcional para os militares da Espanha, mas negava-lhes acesso à tecnologia, à formação e aos soldos para acompanharem seus congêneres. Ao contrário, as FFAA do período final do franquismo exigiam de seus homens 
submissão ao ditador e duplo emprego, quebrando uma das principais regras da burocracia moderna: exclusividade de emprego e regulamentação estrita de funções.

Além de isoladas relativamente às suas parceiras exteriores, as FFAA foram isoladas internamente. Desde o início de seu governo, Franco adotou uma política para depurar a sociedade, especialmente as FFAA, dos valores que estes comungavam ao longo dos anos de Guerra Civil. Como o nível de exigência era maior para o setor castrense, este deveria manterse completamente ilhado relativamente à sociedade da qual eram parte, pois esta era imperfeita e as FFAA, como a elite responsável por manter as essências pátrias, seu último recurso, não poderiam ser "contaminadas" pelas idéias que aquela poderia desenvolver (Caneiro I, [2008] s/d.: 5).

Por último, mas não menos importante, fazer das FFAA a base mais importante do governo e circunscrever quase que completamente sua atuação à segurança interna e seu emprego, particularmente do Exército, à força repressiva, politizou-as e tornou-as obsoletas e subdesenvolvidas, corruptas e incompetentes. Por isso, as reformas promovidas nos anos 1960, não foram suficientes. Ao contrário, serviram para mostrar que o descontentamento estava se instalando no seio castrense, o que causaria, mais cedo ou mais tarde, divisões e cizânia nas FFAA. Exemplo do desenvolvimento de facções internas às Forças está no nascimento da Unión Militar Democrática (UMC) cuja presença no cenário político era comum já no início dos anos 1970 (Barrios, op. cit.).

A tudo isso, deve-se somar a rápida mudança política e econômica que se produziu na Espanha no pós II Guerra. Do ponto de vista político, parcialmente comentado, as próprias escolhas econômicas exigiam alguma liberdade, como as relacionadas às negociações e representações sindicais. $\mathrm{Na}$ economia, vivenciou-se uma rápida industrialização que promoveu a redistribuição territorial e ocupacional da população, fazendo a passagem de uma sociedade predominante rural, a outra, industrial e urbana; de uma classe de camponeses para uma classe de operários e funcionários, o que afetou 
APONTAMENTOS À ANÁLISE DA REFORMA MILITAR...

profundamente a estrutura da elite e a natureza de seus problemas (Maravall \& Santamaría, 1988: 113-5).

Nos anos 1960, Franco percebeu que o regime deveria promover algumas mudanças se quisesse se preservar, pois já não existia a coesão da elite em torno da ditadura, os trabalhadores e setores das classes médias se organizavam, enquanto a intensificação repressiva não parecia atingir resultados. Para responder à crise que se avizinhava, o ditador cede e realiza reformas pontuais.

Quanto às FFAA, conforme já mencionado, a partir de 1965, introduziram-se reformas objetivando adaptá-las às crescentes mudanças. A primeira e mais importante medida reformadora acontece em 1964, com a criação do Centro Superior de Estudos da Defesa Nacional (CEDESEN), que unificou os estudos de Estado Maior das três Forças, preparando tecnicamente seus membros para operações militares. Em seguida, agrupou-as na Escola Superior das FFAA, no intuito de formar oficiais generais (Barrios, op. cit.: 23).

No início dos 1970, outras mudanças seriam promovidas pelo próprio regime. Conforme resume arguto analista:

(...) [a revisão do regime] iniciou-se com a reforma dos sistemas de seleção e formação da oficialidade dos quadros de mando profissionais, cujo ingresso e programa de estudo renovaram-se. Pela primeira vez [desde a criação das FFAA] era exigido que fizessem um curso composto de temática acadêmica e com professores universitários, ainda que realizado em escolas militares, para a seleção das Academias. Também se incorporou aos suboficiais a um regime acadêmico regulamentado. (Caneiro, op. cit. : 3).

Outro evento de suma significância foi a dissolução do Gabinete em 1969, conseqüência do impasse no interior da facção dominante produzido pelas questões relativas à aprovação da Lei Orgânica do Estado que, entre outras coisas, determinava que Juan Carlos de Borbón seria o sucessor de Franco. Aprovada em 1966, foi seguida pelo aumento do 
confronto entre Opus Dei e Falange, as facções que, junto com as FFAA, compunham o governo. No interior desse embate, veio à publico denúncias que redundaram no maior escândalo financeiro da Espanha, o qual envolvia praticamente a totalidade do Gabinete.

Em seguida à dissolução, Franco formou novo governo cuja presidência coube ao Almirante Luis Carrero Blanco, que desenhou um gabinete completamente monolítico em torno da Opus Dei, perfil que implicou no bloqueio da estruturação de uma legislação liberal que contentaria a elite e ampliou o espectro de alvos da repressão. As FFAA eram alvo privilegiado das oposições e o governo apenas reverberou ainda mais esta característica, daí o presidente ter sido assassinado em um atentado assumido pelo ETA (Garcés, op. cit.: 164-66).

Também a Revolução dos Cravos influenciou a forma assumida pelo pós-franquismo. Em abril de 1974, e sem disparar um tiro sequer, um grupo de capitães portugueses colocava um ponto final a uma ditadura de mais de 40 anos. Franco, já alquebrado pela doença (em junho do mesmo ano ele se afastaria da política para não mais voltar), apenas assistiu e, quiçá, tenha tido a visão do que ele, de fato, legaria à Espanha. Naquele momento já se sabia das relações entre UMD e os militares portugueses. Porém, diferente do seu vizinho, na Espanha não se produziu nenhuma revolta que representasse questionamento da hierarquia. Ao contrário, as reformas promovidas logo depois do desaparecimento de Franco do centro político, foram processadas pela ou em conformidade com a alta hierarquia castrense (Caneiro, op. cit.).

Em novembro de 1975, o caudilho morreria e em seguida, seguindo o expressamente estabelecido por Franco 6 anos antes, Juan Carlos foi proclamado rei da Espanha. Iniciava-se, assim, a transição espanhola que, até 1976, seria considerada em preparação, pois sequer havia consenso a respeito da sobrevivência da monarquia. 
APONTAMENTOS À ANÁLISE DA REFORMA MILITAR...

\section{Militares na Espanha pós-franquista}

Todas as entrevistas que tivemos oportunidade de realizar afirmaram a mesma coisa: a personalidade de Don Juan Carlos e a forma como ele lidou com sua escolha por Franco foi fundamental para o processo de transição. Todos afirmaram que se a moderação não prevalecesse, o caminho poderia ter sido detido ou mesmo ter como conseqüência uma nova forma de ditadura ou o retorno à guerra civil. ${ }^{6}$

Em sua investidura, em 22/11/1975, o novo rei lembra que, já em nota divulgada em 22/07/1969, por ocasião da sua proclamação como sucessor de Franco - é bom lembrar, por vontade única deste -, havia informado que quando a ocasião chegasse, seria "o rei de todos os espanhóis". Com isso, Dom Juan Carlos aponta que respeitaria as diferenças entre aqueles povos que formam a Espanha e não faria distinção entre eles. Assim, fala que "a instituição que personifico integra a todos os espanhóis" (grifos meus) e também "a todos nos incumbe por igual o dever de servir a Espanha".

Ainda que indiretamente, o rei afirma seu compromisso com o restabelecimento da democracia, dizendo que há um entrelaçamento entre monarquia e democracia e seu compromisso é promover a institucionalização deste entrelaçamento, pois não existe possibilidade de funcionamento regular da monarquia sem as liberdades democráticas e viceversa: "uma sociedade livre e moderna requer a participação de todos nos foros de decisão, nos meios de informação, nos diversos níveis educativos e no controle da riqueza nacional" e o Rei, como representante da monarquia, deve ser "o primeiro espanhol a cumprir com seu dever".

Ao contrário de tudo isso, talvez com o intuito de mostrarse acima das ideologias expressada por seu "desejo ser capaz de atuar como moderador, como guardião do sistema constitucional e como promotor da justiça", repete sua concordância com o regime sob Franco ao dizer que ele foi "uma figura excepcional [que agora] entra para a história", e vai além ao dizer que os espanhóis devem lembrar do "soldado e 
estadista" (grifos meus) que "consagrou sua existência a servir à Nação". Outra explicação para esse posicionamento relativamente ao regime anterior pode ser a necessidade de garantir para os mais próximos ao franquismo como bem desejara o caudilho, que o rei não representava perigo de grandes mudanças, mas a manutenção do mesmo caminho traçado quase meio século antes.

O interessante a observar relativamente ao papel do rei e na aceitação da monarquia é que a realidade não apontava para isso e os dois primeiros anos desde a morte de Franco foram particularmente críticos para a formação de um governo que pavimentasse o caminho para a democracia. Exemplo significativo é dado por algumas sondagens relativas às preferências populares sobre qual regime político era preferido. Feitas desde o início da década, apontam para as contradições do processo de transição e da incerteza a que este esteve sujeito, é o que mostra a tabela que reproduzimos a seguir:

Tabela 1:

Preferência de Regime Político para pós-Franco por categoria (\%)

\begin{tabular}{|l|c|c|c|c|c|}
\hline $\begin{array}{l}\text { Sistema } \\
\text { Preferido }\end{array}$ & Estudantes & Advogados & Empregados & Médicos & Operários \\
\hline República & 76 & 53 & 45 & 43 & 30 \\
\hline $\begin{array}{c}\text { Regime atual } \\
\text { (ditadura) }\end{array}$ & 01 & 08 & 37 & 20 & 55 \\
\hline Monarquia* $^{*}$ & 16 & 34 & 13 & 27 & 11 \\
\hline
\end{tabular}

*A preferência pela monarquia se dividia entre as linhagens Borbónica (vitoriosa), carlista (do irmão do pai do Rei atual) e indiferente.

FONTE: Fundación FOESSA, 1970. Citado em Garcés, op. cit.: 171.

Os dados apontados na Tabela tornam difícil compreender como, em tão curto espaço de tempo, a Monarquia, regime que não era relativamente mais preferido em nenhuma das categorias avaliadas pôde se efetivar e em tão curto espaço de tempo. Outra informação interessante é que o regime republicano só perdia na preferência dos operários, para os 
APONTAMENTOS À ANÁLISE DA REFORMA MILITAR...

quais a ditadura era o regime preferido. Mesmo nesta categoria, o regime monárquico não chega a ser expressivo, apresentando um percentual menor que a metade do que a preferência pelo regime republicano.

Tomando a direção inversa, enfatizando os dados não apresentados na tabela, como a preferência da Igreja, das FFAA e dos empresários, podem sugerir a força relativa destas categorias, pois puderam não apenas sustentar um regime autoritário e pessoal durante mais de 30 anos, mas também impor a direção do regime que o substituiria e também o ritmo da transição entre eles. Também podem ser indicativos da permanência de Franco, mesmo depois de morto, nos destinos da Espanha.

Relativamente às FFAA, se não temos certeza sobre suas preferências quanto ao regime, sabemos sobre sua divisão interna. Além do aparecimento da UMD, que congregava tanto oficiais monarquistas como republicanos, vários autores chamam a atenção para a existência de visões diferentes das impostas por Franco que foram pouco a pouco se apresentando no interior do próprio governo. Também a centralização decisória em si e a desconfiança que alimentava até mesmo com relação aos seus colaboradores mais íntimos, impediu o aparecimento de qualquer líder no meio militar, fazendo com que as lealdades se transferissem de Franco para seu sucessor.

Da mesma forma que nossos entrevistados mencionaram a postura do rei como importante para o a sucessão pacífica da ditadura, também afirmam ter sido fundamental o papel desempenhado por aqueles militares que estiveram envolvidos com as reformas promovidas nas FFAA. Neste aspecto, citam como exemplo o general Díez Alegria, que buscou introduzir diversas medidas no sentido de afastar os militares da política desde 1969, quando esteve na direção do Centro Superior de Estudos para a Defesa Nacional (CEDESEN), criado por Franco em 1964. Realçam o papel fundamental de Díez Alegria, e depois de Gutiérrez Mellado, na criação das bases internas para que as mudanças fossem incorporadas sem conflitos imprevistos. ${ }^{7}$ 
Até 1976, com a renúncia do Primeiro-Ministro Carlos Arias Navarro (Movimento Nacional), ${ }^{8}$ pouco mais que expectativas foram vividas pelo novo regime que se avizinhava. No exterior, as oposições se organizavam em torno de uma plataforma de convergência enquanto no interior do país a população estava cada vez mais mobilizada, ${ }^{9}$ em especial o movimento operário que mostrou que sua capacidade combativa não tinha sido debelada apesar da intensa repressão a que estivera sujeito (Maravall \& Santamaria, op. cit.: 124).

Em seguida, assume o governo Adolfo Soares (1976-81), da União de Centro Democrático (UCD) que teve habilidade suficiente para moderar as relações entre os radicais de ambos os lados, os da burocracia e das Cortes (o Parlamento espanhol) que defendiam a permanência dos ideais franquistas, e dos opositores que buscavam desde a monarquia constitucional, passando pela república, até o socialismo.

Sob a liderança de Soares foram construídos diversos acordos que representaram concessões, às vezes estruturais, de todos os atores, em especial os representantes dos "partidos" e do próprio governo. Tanto o Primeiro Ministro quanto o Rei adotaram posturas que forçaram os atores envolvidos a negociar. Conseguiram definir o campo e os limites dos pactos e também envolver todas as frações do universo político.

Relativamente à oposição, suas duas principais concessões foram a garantia de não punição aos envolvidos na repressão sob a ditadura e o recuo na defesa do republicanismo. Mas não parou por ai: não conseguiram brechas para políticas econômicas menos conservadoras e aceitaram as regras de proporcionalidade política que favoreciam claramente as forças reacionárias.

Já com relação aos partidários da ordem, fez com que aceitassem seu projeto de reforma política, que defendia a democracia e, conseqüentemente, a organização de partidos e o respeito às eleições. Para tanto, Soares os convenceu que haveria continuidade nos cargos e respeito à legalidade. Também compeliu-os a aceitar a participação do Partido 
APONTAMENTOS À ANÁLISE DA REFORMA MILITAR...

Comunista Espanhol (PCE) nas eleições e a dissolução do MN e a reorganização dos sindicatos.

Pode-se dizer que a reação foi mais feliz que a oposição em aprovar sua pauta de reivindicações, o que se confirma pela permanência de vários nomes do franquismo depois das eleições de 1977. No entanto, não se pode afirmar que foi pela força de Soares ou do Rei que se alcançou este resultado. Ao contrário, à esquerda deve ser creditada parte da responsabilidade, pois não foi capaz de convencer a população que o programa de Soares não merecia sua adesão: enquanto defendiam a abstenção, 74\% dos eleitores compareceram às urnas e a transição para a democracia foi aceita por quase unanimidade: $94 \%$ dos eleitores a aprovaram (Maravall \& Santamaria, op. cit.: 127).

Após ganhar as eleições de 1977, Soares formou seu gabinete agregando diferentes forças. Para primeiro viceministro, ele escolhe o único militar do seu gabinete, o General Gutiérrez Mellado, que conduzirá também o Ministério da Defesa. Não se pode esquecer que quando assume o governo, Suárez herdou três ministérios militares, o que mudou justamente com a presença de Gutiérrez Mellado no Gabinete, que decidiu pela criação de um novo ministério, o Ministério da Defesa, que reuniria as três pastas singulares dedicadas a cada uma das Forças e tornando cada um dos chefes de Estado Maior em Comandante da Força respectiva. (Puell de la Villa, 1977: 144 ss.).

Antes da nova configuração ministerial, o governo havia regulamentado a Junta de Jefes de Estado Mayor (JUJEM), à qual cabia, como órgão colegiado máximo das três Forças, propor o Plano Estratégico Conjunto - em cuja elaboração não existia participação do governo -, conduzi-lo e coordenar os planos que dele derivassem, bem como regular a doutrina das FFAA. No entanto, a própria ambigüidade da Lei permitia que o Ministério da Defesa fosse ultrapassado, pois a JUJEM tinha acesso direto ao Rei, que era seu Comandante-em-Chefe, permitindo legalmente a continuidade da autonomia militar (Caneiro, op. cit., 11). 
Também se mantém o serviço militar obrigatório para os homens e continua a ser vetado às mulheres adentrar às FFAA. Da mesma forma, são mantidas as divisões por região militar. Entretanto, ainda que permanecendo semelhante à sua predecessora, a jurisdição da Justiça Militar se retrai e já não é competente para julgar civis, mesmo aqueles acusados de crimes contra a segurança do Estado (Ib.: 12).

Naquele momento da transição, ${ }^{10}$ os atores que queriam avançar no processo de democratização eram poucos, ao que pode ser atribuída a timidez das reformas postas em prática. Mesmo quando acontecia como aqui descrito, o governo pisava em ovos e procurava tirar vantagens disso. Mas também é relevante as tentativas de restrição ao raio de autonomia militar, como é exemplo a regulamentação da JUJEN ainda no governo Suares, que busca superar as resistências internas e se impor definitivamente a elas (Puell de la Villa, op. cit.).

Nestes primeiros anos de transição, no qual o equilíbrio entre os atores políticos acontecia por concessões mútuas, os oficiais superiores das FFAA que ocupavam cargos de mando eram, em sua maioria, contra as reformas, mas estas avançavam sem interferência militar, porque “... os militares haviam sido educados em uma cultura freqüentemente anti-intervencionista, resultado de um paradoxo do regime ditatorial ..." (Caneiro, op. cit.: 13, grifos nossos).

Em junho de 1977, realizam-se as primeiras eleições relativamente livres desde 1936 que, pelas características do que fora antes pactuado, mas com o PCE legalizado, faz com que a UCD obtenha o maior número de cadeiras. ${ }^{11}$ Seguindo a mesma dinâmica adotada antes, Suares escolhe a negociação como base de gestão que, tendo como pano de fundo a forte crise econômica que assolava o país, levou aos Pactos de la Moncloa. ${ }^{12}$

Representantes reunidos, votam pela transformação das Cortes em Assembléia Constituinte e passam, então, a discutir uma nova Constituição para a Espanha, que será publicada pouco mais de um ano depois, em 31 de outubro de 1978, ratificada em referendum de 06 de dezembro do mesmo ano. A nova Constituição não deixava dúvidas sobre a subordinação 
APONTAMENTOS À ANÁLISE DA REFORMA MILITAR...

militar ao poder civil, o que causou grandes discussões interna corporis, pois os membros das FFAA, ainda se definiam como guardiães da ordem e últimos bastiões dos valores pátrios (Serra, op. cit.). Segundo o artigo $8^{\circ}$ da Constituição,

As Forças Armadas, constituídas pelo Exército, Matinha e Aeronáutica, têm como missão garantir a soberania e independência da Espanha, defender sua integridade territorial e o ordenamento constitucional (Constituição de Espanha, 1978).

Informavam ainda que uma Lei orgânica explicitaria a organização conforme os princípios constitucionais (art. $8^{\circ}$ ); que os militares somente podem exercer o direito de dirigir petições ao governo de forma individual (art. 29 ${ }^{\circ}$; entende que a defesa da Espanha é direito e dever de todos, mantém o serviço militar obrigatório, mas aceita a objeção de consciência, com possibilidade de exercício de serviço civil alternativo e deixa para uma Lei regular os deveres dos cidadão em momentos de catástrofe (Art. 30). Já o Comando-em-Chefe das FFAA e a representação do Estado pertence ao Rei (Art. 62 $\mathrm{h}$ ). Também subordina a Justiça Militar ao Supremo Tribunal (Art. 123), colocando fim à dualidade até então existente.

Pode passar despercebido, mas outro preceito importante encontra-se no Artigo 97\%, que determina: "O Governo dirige a política interior e exterior, a administração civil e militar e a defesa do Estado ..." A importância não está na determinação em si, mas na presença, na mesma divisa constitucional, da concentração nas mãos do governo tanto da defesa como da política exterior. Pode-se ler que tanto uma quanto outra são políticas indissociáveis e, portanto, uma não pode ser pensada sem a outra.

Conforme um analista, os Pactos de Moncloa foram importantes não apenas pelo que decidiram no momento em que foram firmados, mas também porque estabeleceram o consenso como regra para as transformações que adviriam sem que gerassem conflitos que pudessem "travar" a transição. Assim, foi "a regra do consenso [que] permitiu que o artigo $8^{\circ}$, tão 
surpreendente em nossa história constitucional, não tenha sido objeto de especial polêmica (...) Parece que os constituintes tinham claro desde o primeiro momento (...)" o que seria definitivamente aprovado (Suárez Pertierra, 2004: 100).

A Lei a que se refere o Art. $8^{\circ}$, veio à publico em 10/06/1980, por meio da Lei Orgânica 6/1980, de $1^{\circ}$ de julho do mesmo ano. Ela foi feita quando o ministro da Defesa era Rodriguez Sahún, o primeiro civil a ocupar o cargo, assumindo em abril de $1979,{ }^{13}$ que sequer tinha um espaço específico para exercer suas funções, e regulava os aspectos básicos da Defesa Nacional e da Organização Militar.

Desta Lei, merece ser ressaltado seu Art. $4^{\circ}$, que determina que "1. A política de defesa, como parte integrante da política geral, determina os objetivos da Defesa Nacional e os recursos e ações necessários para obtê-los" (BOE $n^{\circ} 165$, grifos meus) Em seguida, regulamenta qual a relação entre Defesa Nacional e FFAA, mostrando a hierarquia entre as políticas: "2. A política militar, componente essencial da política de defesa, determina a organização, preparação e atualização do potencial militar, constituído fundamentalmente pelo Exército, a Armada e a Força Aérea, tendo em conta as possibilidades da Nação em relação com a defesa" (Ib., grifos meus).

Os trechos grifados mostram uma característica fundamental para concentrar as decisões relativamente à área da defesa na mão dos civis, bem como estabelece como deverá ser a relação entre civis e militares na democracia. Na verdade, sem a capacidade de determinar a política militar como qualquer outra política do governo ou Estado, os civis não podem dizer que foram bem sucedidos no estabelecimento de um regime democrático, muito menos se a interferência castrense na formulação das políticas de defesa e mesmo da militar for além do auxilio técnico aos que devem decidir: os políticos.

A Lei 6/1980, manteve a organização territorial por Regiões Militares e também o Serviço Militar Obrigatório, que continuava um dever prioritário dos cidadãos e sem permitir a ascensão das mulheres à carreira castrense, mas incorporou a objeção de consciência que deveria substituir o primeiro pela realização de 
APONTAMENTOS À ANÁLISE DA REFORMA MILITAR...

serviços sociais, o que jamais se transformou em lei, dificultando, pois, a realização deste direito (Caneiro, op. cit., p. 11).

Redigida e promulgada a Constituição, tanto o governo quanto o maior partido de oposição, o PSOE, passaram a agir como se já estivessem em uma democracia plena, abandonando a moderação que havia caracterizado os avanços até então conquistados e ignorando que as mudanças, principalmente nos cargos de comando das FFAA, não haviam produzido efeito pretendido porque eram muito recentes e os militares conservadores e os abertamente reacionários continuavam a ser maioria no interior das Forças, em especial do Exército.

Acrescenta-se a isto o aumento das ações do ETA que, em 1980, produzia uma vítima (mortos e feridos) a cada dois dias, bem como o crescimento das reivindicações e manifestações dos partidos nacionalistas (regionais) contra a centralização das nacionalidades no Estado espanhol. Também a crise econômica não se mostrava solucionável a curto prazo, o que significou que não houve nenhuma melhora palpável para as FFAA, já em péssima situação nos estertores do franquismo. Com isso, criase o caldo de cultura para que prevaleça maior incerteza e reverberou na tentativa de golpe militar, em 23 de fevereiro de 1981.

A tentativa de golpe promoveu-se no momento da investidura do novo governo, Leopoldo Calvo Sotelo (UCD, 198182), quando um grupo militar liderado pelo Tenente-Coronel Antonio Tejero, invadiu o Congresso no intuito de criar um vazio de poder que permitisse erigir um novo regime político que manteria o rei, mas concederia maior poder de decisão aos militares.

O golpe não foi uma atitude isolada. Enquanto um grupo mantinha o Congresso impotente pela ponta das baionetas, outro grupo tomava a Rádio e Televisão Espanhola - maior meio de comunicação do país na época - e o Capitão-General Jaime Milans Del Bosch, comandante da III Região Militar, em Valencia, também se sublevava, invadindo o centro de Valencia e acuando seus governantes.

HISTÓRIA, São Paulo, 28 (2): 2009 
A atuação de Gutiérrez Mellado, vice-presidente demissionário, e militar de mais alta patente no Congresso quando da ação de Tejero, foi extremamente importante, pois ele não apenas desobedeceu as ordens de Tejero como assumiu postura de comando tentando convencê-lo da sandice que estava liderando. A atitude do Rei foi ambígua, pois ao mesmo tempo que pedia a manutenção da legalidade constitucional, os golpistas afirmavam que ele estava a par do golpe. Ao final, entretanto, colocou-se plenamente ao lado da Constituição.

Não foram, entretanto, as atitudes indicadas que levaram ao fracasso do golpe; muito mais significativas foram as divisões internas às próprias Forças. "O que sucedeu com os onze comandos das regiões militares foi indicador significativo da divisão interna nas FFAA. Enquanto uma região se somou ao golpe, três se manifestaram contrárias e as restantes não se definiram" (Canero, op. cit.: 15). A atitude dos golpistas e depois daqueles que os julgaram, pareceu colocar uma pá de cal em veleidades semelhantes, facilitando as reformas que estavam por vir.

\section{A época das Reformas}

Com as eleições de 1982, das quais sai vitorioso o PSOE, constituindo o governo em dezembro do mesmo ano, o período de transição na Espanha tem seu ponto final e se inicia um novo período, ainda prenhe de necessidades reformistas, mas quando a incerteza sobre o regime político foi superada. Neste momento, inicia-se o governo de Felipe Gonzáles, que permaneceria como líder por 14 anos, tempo que, se parece largo, não foi suficiente para que se colocasse em prática todas as reformas pretendidas.

É importante destacar que, ao contrário de outros partidos, - PSOE emprestava grande preocupação relativamente aos assuntos militares e de defesa. Desde seu $27^{\circ}$ Congresso, de 1976, discutia-se como deveriam superar o anti-militarismo tradicional dos partidos socialistas para abraçar a necessária causa de incorporar os militares à Democracia. A aceitação da 
APONTAMENTOS À ANÁLISE DA REFORMA MILITAR...

monarquia parlamentar e do regime democrático, impôs ao partido escolhas que quase o destroçaram, sendo a principal delas o abandono dos postulados marxistas, em 1978. Porém, a renovação dos princípios partidários foi fundamental para seu próprio desenvolvimento e repercutiram sobremaneira no desenho que o PSOE fez para levar a cabo o que se entendia como "necessárias reformas no âmbito castrense".

Chegando ao poder, o PSOE passou a propor um pacote de leis com o objetivo de submeter definitivamente as FFAA ao poder civil, transformando-as em o "grande mudo" da política e acabando definitivamente com seu controle sobre atividades estritamente civis, como a aviação civil e a marinha mercante, bem como transferiu para o setor civil serviços de atenção às Forças, como os de saúde e educação.

No programa de governo, Felipe Gonzáles comprometeu-se a convocar um referendum para manter ou não a Espanha na OTAN, cuja entrada tinha sido promovida no final do governo anterior sob forte resistência do PSOE. Porém, talvez por entender que assim deveria permanecer, a votação aconteceu apenas em 1986, com a vitória inesperada pela permanência. No mesmo ano, o país entra para a Comunidade Européia e faz parte dos 12 países que firmam o Tratado de Maastricht, em 07/02/1992, criando a União Européia.

Nas entrevistas realizadas com militares ou ex-militares, um dos quais responsável pela área de educação do MD em parte do mandato de Narcís Serra (1982-1991), eles insistiram na importância da entrada da Espanha nas duas organizações acima, em especial na primeira. A participação do país nessas organizações ressoou tanto na sociedade civil quanto nos meios militares.

No âmbito da sociedade civil, a adesão do país à OTAN, ainda que num primeiro momento sem integrar sua estrutura militar, foi apreendida pelos espanhóis como a abertura real da janela para a Europa, ou melhor, como se o Continente tivesse relevado os quase meio século de ditadura e dessem uma nova chance ao país, desde que este se comprometesse com a real edificação de um regime democrático. Essa percepção foi 
fundamental para assegurar que o povo espanhol não aceitaria retrocessos.

Nas FFAA, ainda que como observadores nas campanhas da OTAN, a participação dos militares foi auto-percebida como, por um lado, uma forma de comparar o desenvolvimento de seus congêneres e o seu próprio, mostrando-lhes o quanto estavam longe de uma estrutura militar profissional; por outro lado, como uma maneira de ao menos equilibrar a ligação entre as FFAA espanholas e norte-americanas, reforçando a primeira percepção e, ao mesmo tempo, apontando para novas alternativas. Essas razões fortaleceram a crença na democracia e, conseqüentemente, na subordinação militar ao poder civil, pois se apresentavam como o melhor caminho para a profissionalização das FFAA e sua adequação, pelo crescente desenvolvimento, aos padrões europeus.

Desde o primeiro ano de governo, o PSOE passa a promover a reforma do setor militar. Assim, é publicada a Lei 1/1984, que trata dos critérios básicos da Defesa Nacional e Organização Militar, superando as ambigüidades da Lei 6/1980 e especificando melhor as competências do governo na matéria, bem como transformando a JUJEM em órgão de assessoramento do governo e, talvez o mais importante, concentra nas mãos do Ministério da Defesa as funções decisórias, desde compras de material até a supervisão do ensino militar.

Outras medidas de igual calão são a reestruturação do Ministério da Defesa (Real Decreto 135/1984); a transformação da Subsecretaria de Estado de Defesa em Secretaria de Estado de Administração Militar e que passa a ser responsável pela direção das políticas de pessoal e ensino para as FFAA (Real Decreto 619/1990), o que implica na passagem dos Comandos das Forças para o terceiro nível administrativo e, mais importante, por meio da Lei 9/1985, se cria o Corpo Militar de Intervenção da Defesa, que se constitui pela integração dos três corpos das Forças singulares.

As reformas promovidas fazem com que, em menos de dez anos, o quadro de funcionários do $\mathrm{MD}$ quase se equilibre entre militares e civis. Segundo pesquisa realizada por Agüero (1995), 
APONTAMENTOS À ANÁLISE DA REFORMA MILITAR...

enquanto os civis ocupavam, em 1984, 17\% do total de altos cargos contra 83\% ocupados por militares, em 1993, os civis ocupavam $45 \%$ e os militares $55 \%$ deste total (Apud Caneiro, op. cit.: 24).

No que se refere à política de pessoal, a reforma mais importante não se resumiu à estrutura do $\mathrm{MD}$, mas a reestruturação das FFAA que, segundo estudo de uma comissão inter-setorial, eram inchadas e ineficientes. Assim, em pouco mais de dez anos, se promoveu uma redução de $90 \%$ nos quadros das FFAA, ${ }^{14}$ tanto pela passagem para a reserva por meio do mecanismo nomeado de Reserva Transitória, como pela diminuição da idade de passagem para a reserva, aplicada por meio de uma escala progressiva. A Força mais afetada por esse processo foi o Exército, juntamente porque era a que mais fora utilizada na manutenção da ordem interna.

Segundo Gustavo Suárez Perierra, ${ }^{15}$ nomeado ministro da Defesa no último ano do governo Gonzáles, mas que vinha acompanhando o que se passava no setor castrense desde o início da transição, seja como deputado, ministro da Educação e Secretário do Ministério da Defesa, o mecanismo para reduzir o pessoal militar, foi engenhoso e contou com uma série de fatores positivos, sendo o mais importante a vontade política que destinou recursos substanciais para que se chegasse ao objetivo almejado, ou seja, a profissionalização das Forças.

A construção deste novo corpo profissional, sempre acompanhando o raciocínio de Suárez Pertierra, necessariamente pequeno, coeso e eficiente, foi feito por meio de três mecanismos sucessivos, postos em prática de forma quase simultânea, mas respeitando outras reformas também impactantes para as FFAA. Os mecanismos foram: a Reserva Provisória (Real Decreto 1000/1985); a redução progressiva de postos (Real Decreto 46/1985) e a abolição do Serviço Militar Obrigatório (Lei Orgânica do Serviço Militar, de 1991).

A redução progressiva de postos é uma medida administrativa revisada e publicada periodicamente (para soldados e baixo oficialato, normalmente a relação de postos é anual, enquanto para o oficialato depende de fatores mais 
amplos e por isso a periodicidade é maior) que estabelece as vagas em cada um dos postos (patentes) das FFAA. Na Espanha, o que se fez foi acabar com "Plazas de Gracia", postos criados para incorporar maior número de oficiais-generais do que o necessário para cada Força, e promover a redução gradual dos postos superiores ano a ano. Essa última medida, além de formar a pirâmide que corresponde à burocracia eficiente, permitia que um número maior de oficiais passasse para a reserva sem chegar ao topo da carreira.

Das três medidas, a mais complicada para o PSOE era a abolição do Serviço Militar Obrigatório. Isso porque, como partido socialista, era difícil conjuminar a tradição de "povo em armas", entendido como um direito e um dever - daí a conscrição universal -, em exercício completamente voluntário da força. Neste último caso, o PSOE teve que ser convencido que se tratava de uma extensão de direitos e a permanência de um dever a partir da extensão das definições presentes nos termos dever e direitos, da mesma forma que exigia a nova definição de força armada. Portanto, para atender às novas necessidades sem transigir imediatamente com as escolhas do próprio Partido, adotou-se uma fórmula pela qual, estabelecido o total de efetivos das FFAA, se mantinha o Serviço Militar Obrigatório, mas aumentando ano a ano o percentual de voluntários, o que redundou na eliminação completa do serviço obrigatório em 2000 (Lei 14/1993).

Por último, mas não menos importante, colocou-se em marcha a "reserva transitória". Esse mecanismo, que visava sobre tudo a redução de pessoal, é semelhante ao que conhecemos como "aposentadoria voluntária" - pedido pelo interessado que recebe incentivos para se aposentar antes do previsto -, exceto por duas características que fazem dele único: 1) era aplicado a todo pessoal do Exército (exceto generais), ${ }^{16}$ não havendo critério etário ou de tempo de serviço para se candidatar. $\mathrm{O}$ critério adotado era o percentual de pessoal a ser passado para a reserva em determinado posto/função. Esse percentual era definido anualmente pelo MD. Se o número de candidatos aptos ultrapassasse o de postos a serem extintos, 
APONTAMENTOS À ANÁLISE DA REFORMA MILITAR...

seguiam-se critérios gerais de passagem para a reserva (idade, tempo de serviço, pontos por mérito, etc.). Era irreversível, isto é, aquele que passasse para a reserva transitória, assim permaneceria até alcançar a idade para sua efetiva passagem para a reserva, ou permanecesse na reserva transitória por 15 anos; 2) os incentivos para a candidatura à "reserva voluntária" incluíam, além da manutenção integral do soldo recebido, todas as vantagens que o posto determinado garantia ao oficial como se este continuasse na ativa. Assim, todo aquele que entrasse neste programa teria direito aos reajustes no soldo, os ganhos por função, por tempo de serviço e qualquer outro que não fosse individualmente aplicado aos militares da ativa. Era incompatível com o exercício de outros cargos públicos, isto é, aquele que passasse para a reserva transitória não poderia acumular salário se desejasse e efetivamente cumprisse outro cargo na administração estatal, em qualquer de seus níveis.

Infelizmente, não tive acesso à informação particular de cada um desses mecanismos e, portanto, não tenho como mostrar, por meio de números, o impacto de cada um sobre o redesenho das FFAA espanholas. O que sim posso dizer é que a reserva transitória foi a medida menos polêmica, mas nem por isso menos eficiente, na redução das FFAA, pois foi por meio dela que se subtraíram oficiais militares do serviço ativo, o que significa redução imediata no efetivo militar. Ele deve ter sido bastante eficaz também porque foi extinto apenas em 2002, isto é, foi utilizado por quase 20 anos, o que não significa que aqueles que estavam na reserva transitória não permaneçam, ainda hoje, nesta situação.

Não se tratava, entretanto, de apenas reduzir as FFAA, pois se entendia como imprescindível à Espanha possuir FFAA profissionais e eficientes, de forma a se equiparar, também por essa via, aos países europeus. Por isso, paralelamente às políticas de redução dessas Forças, foram promovidas políticas de apoio profissional tais como a equiparação dos soldos aos salários do funcionalismo público civil; programa de residência o militar terá direito à sua residência quantas vezes seja deslocado em razão do serviço, tendo o direito de levar sua HISTÓRIA, São Paulo, 28 (2): 2009 
família -, retribuições por mérito (como acontece no funcionalismo civil), além de uma política de aquisição de equipamentos e armas que permitiram a modernização bélica do país.

Duas outras mudanças foram promovidas nas Forças Armadas, ambas com impacto na integração das FFAA à democracia, mas com objetivos diversos. A primeira foi a incorporação das mulheres às FFAA. Neste caso, o objetivo era responder a uma medida constitucional, a igualdade de gênero, parte da definição de cidadão e, portanto, o Estado está sujeito a respeitar. A outra foi a reformulação da educação militar. A finalidade aqui é muito menos visível, pois se trata de influenciar no próprio ethos militar, de forma a tornar o comportamento castrense, produto desse ethos, compatível com o regime político. Trata-se de fazer das FFAA instrumentos da defesa e respeitadoras das regras democráticas sem deixar de ser organização total, fundamentada na hierarquia e na disciplina.

No que se refere à incorporação das mulheres, há pouca coisa a dizer aqui. Elas passaram a fazer parte das Forças em 1988, mas com uma série de restrições que pouco a pouco foram sendo superadas. Hoje, há mulheres em quase todos os postos, mas, ainda assim, há poucas mulheres nas armas combatentes, entendidas como especificamente militares, pois sua ascensão a todos os postos e Armas aconteceu em época muito mais recente (1999). Esse é um tema que vimos trabalhando recentemente, razão pela o qual o deixamos para outra oportunidade.

Sobre a educação militar, este é o verdadeiro tema de nossa pesquisa. Nosso interesse, conforme mencionado no início deste texto, é estudar o caso espanhol de reforma do ensino militar como um caso que quase determina a adoção de um modelo. O interesse, pois, é de construir um modelo que torne possível a comparação entre os diversos tipos de educação militar, apontando para quais características são importantes para a real incorporação dos militares à democracia e, portanto, a superação da fase de transição para a da vivência democrática. 
APONTAMENTOS À ANÁLISE DA REFORMA MILITAR...

\section{A Reforma na Educação}

Falar em educação é tratar de um assunto muito amplo e que marca a vida de todos os indivíduos, pois, tomada em seu sentido lato, a educação implica desde o processo de socialização, passando pela formação e instrução. Isso significa que por meio da educação, o sujeito não apenas adquire habilidades e capacitação para determinadas tarefas, mas também incorpora determinados valores. O papel da educação e sua forma de operar é essencial para a construção do cidadão e, tomada como instrução para determinada habilitação (carreira), é fator de progressão e continuidade.

Por sua amplitude, não teríamos condições de tratar da educação em um texto da natureza deste, razão pela qual não podemos tomar a totalidade do tema, ainda que restrito ao âmbito militar. Assim, aqui trabalharemos unicamente com a reforma do ensino militar. A escolha do ensino em detrimento de outros campos está na forma concreta com que este se apresenta ao cientista, isto é, ainda que não se possa apreender a totalidade de como o ensino forma o sujeito, chega-se muito próximo desta totalidade por meios empíricos, tais como: onde são dadas as aulas (escolas isoladas ou não), qual o tipo de escola (civil ou militar; religiosa ou laica), como o aluno freqüenta a escola (externato, semi-internato ou internato), qual a divisão entre instrução e adestramento ou entre ensino propedêutico e ensino específico, etc.

O ensino militar, para repetir as palavras de Caneiro, "... é um modo indireto de saber se foi produzida uma 'transformação' significativa, ou não, desta parte da organização militar que é necessária, mas não suficiente, para a mudança de valores das FFAA de qualquer país." (s/d. II: 7).

No que se refere às mudanças promovidas no ensino militar desde 1975 na Espanha, é importante registrar que não apenas os resultados, mas as próprias mudanças no sistema educativo militar vão além do período de transição, devendo ser reforçado ou abandonado para realmente produzir resultados. Em contrapartida, qualquer alteração promovida no âmbito 
educativo tem alto alcance, isto é, atinge um número grande de sujeitos e por um período largo e, portanto, dificilmente podem ser revertidos ou, quando o são, provocam efeitos não esperados.

O ponto de partida para as reformas são as FFAA que chegam ao fim do franquismo. Para o ensino militar que existia em meados dos anos 1970, podemos usar a seguinte frase "cada sujeito em sua Força, cada Força em sua academia", isto é, existiam três sistemas de ensino militar em funcionamento, cada um para uma força singular. Além disso, duas outras características singularizavam o ensino militar: para ingressar nas academias castrenses era exigido dos candidatos que professassem a fé católica e que provassem "boa conduta moral e social", o que queria dizer que só poderiam ingressar nas academias os filhos de famílias que apoiavam o regime, ou assim fossem consideradas. Era uma forma, portanto, de expurgar das FFAA qualquer risco de oposição.

A última oportunidade de ingresso era aos 22 anos (na Força Aérea, era aos 20 anos), embora se incentivasse que a entrada fosse aos 16 anos, ao término da escolarização obrigatória. O tempo de serviço obrigatório variava de Força para Força, e era nele computado o tempo que se passava em cursos destinados à seleção nas escolas militares, seja nas de formação para sub-oficiais ou para oficiais.

Ainda que variassem de Força para Força, exigia-se um enxoval dos ingressantes nas academias, bem como o pagamento da matrícula e de certos gastos como equipamentos militares. Quando isso não se efetivava até 60 dias após o ingresso, o aluno era jubilado.

Quando ingressavam, o regime era o de internato e o dia a dia era dividido entre quatro ou cinco aulas de 50 minutos cada para disciplinas propedêuticas com ênfase nas matemáticas e mais três horas diárias de instrução. Sobravam, portanto, três a quatro horas para estudo obrigatório e uma ou duas horas de descanso entre as atividades de estudo. Essa era a jornada obrigatória durante cinco dias da semana e mais meia jornada aos sábados. Os domingos eram reservados para descanso, mas 
APONTAMENTOS À ANÁLISE DA REFORMA MILITAR...

tinha-se a assistência à missa como obrigação semanal, especialmente para aqueles que não podiam regressar para suas casas - maioria dos casos, pois os centros de ensino nem sempre se localizavam próximos às residências do alunato, também porque ao candidato não era dado escolher o local no qual iria estudar.

A carreira de professor não era bem vista no interior das FFAA, o que fazia com que muitos deles cumprissem com a tarefa de forma forçada, estimada em quase $44 \%$ em 1974, porque indicados para fazê-lo e sem a menor vocação. Muitos preferiam ser instrutores, isto é, dedicarem-se ao ensino de aspectos técnicos, como marcha ou tiro, razão pela qual cerca de $3 / 4$ deles ficavam mais de um ano nesta função (Fernandes, apud Caneiro, op. cit. II). Talvez por isso, os livros indicados aos alunos eram muito limitados, não apenas em número, mas em temas, e as apostilas, disseminadas sem nenhum controle, reproduziam apontamentos e extratos de conferências realizados nas próprias dependências das Forças e muitas delas eram indicadas sucessivos anos, durante 10 ou mais anos. Embora as escolas contassem com bibliotecas, era bastante provável que o aluno terminasse sua formação sem jamais ter pisado nas suas dependências (Canero, op. cit. II: 10).

Outra característica que limitava bastante o homem de armas e sua identificação com a sociedade da qual fazia parte, era que desde o princípio, isto é, desde seu ingresso em uma escola militar para formação de oficiais, sua carreira estava praticamente definida, pois o principal critério de promoção era o de antiguidade, não fazendo parte da equação nenhum outro estimulo, embora existissem sanções que pudessem prejudicar a carreira. Por tudo isso, os professores militares sabiam serem inferiores aos seus pares civis, mas as academias castrenses estavam fechadas a estes, a menos que se tratasse de um caso estritamente particular e necessário.

Conforme reiteradamente nos foi informado, a reforma militar, especialmente no aspecto da formação da mentalidade, somente pode ser colocada em prática quando se tem definido claramente o que se espera desses militares, isto é, quando 
existe uma norma que informe à sociedade e às suas FFAA quais são as ameaças, como combatê-las e de que modo fazê-lo. Em outras palavras, a reforma dos valores castrenses está condicionada pela presença ou existência de uma Política de Defesa e Militar que determine para quê as FFAA existem e como devem cumprir suas funções. Neste sentido, a despeito da reforma no âmbito do ensino militar ter se iniciado nos primórdios da transição, foi apenas depois da Constituição (1978) e das formulações da Lei de Defesa e Militar que a reforma do setor de ensino teve início efetivo.

Como informado para as demais reformas, a da educação militar foi promovida quando o PSOE formou governo, isto é, entre 1982 e 1996 e depois de 2004. ${ }^{17} \mathrm{Da}$ mesma forma que registramos para as demais políticas, desde 1976, por ocasião do seu $27^{\circ}$ Congresso, o PSOE apontava para a necessidade de mudanças no âmbito militar, colocando, ainda que de forma paulatina, um ponto final na chamada questão militar. Dentre os pontos abordados, estava o relativo ao ensino militar, que era percebido como "instrumento que possibilitaria a integração dos militares profissionais à sociedade" (Caneiro, op. cit II: 25).

Quando no governo, o PSOE passou a empreender medidas no sentido de equiparar os estudos militares aos estudos civis, encarado como forma de facilitar tanto a passagem dos militares para a vida civil quanto como forma de integração dos civis às FFAA, desde que, em ambos os casos, se complementassem os estudos. Por isso, a proposta inicial era a de reduzir a formação específica dirigida pelas academias militares ao mínimo necessário para o desenvolvimento das habilitações castrenses (como o manejo de armas e equipamentos), enquanto tudo o que não fosse exclusivo das técnicas militares fosse cursado em centros civis.

A despeito dos objetivos, cujo principal era tornar intercambiável o ensino recebido pelos militares ou pelos civis considerando o mesmo nível, todas as mudanças no ensino militar foram produto de acordos entre o governo e as FFAA. Isso significou, pelo menos no momento inicial, submeter o entendimento de que se deveria promover a equivalência entre 
APONTAMENTOS À ANÁLISE DA REFORMA MILITAR...

ensino militar e civil a três sistemas de educação diferentes e, portanto, a três formas de compreensão da educação militar.

Apesar dos empecilhos, representados principalmente pela alta hierarquia das FFAA, e contando com o auxilio daqueles militares e civis que tiveram a oportunidade de ter contato com as modernas FFAA européias, algumas mudanças puderam ser introduzidas sem maiores resistências e, em alguns casos, com a colaboração de membros das FFAA. De forma esquemática, citamos:

1) Foram unificadas e racionalizadas as formas de acesso ao ensino militar;

2) Criou-se um único sistema de ensino militar (unificação dos sistemas do Exército, Marinha e Força Aérea);

3) A partir de 1985, adotaram-se medidas para a incorporação de docentes civis ao corpo de professores para as escolas militares;

4) Ao mesmo tempo, criaram-se mecanismos de voluntariado para a incorporação de oficiais militares ao corpo docente das escolas militares;

5) Racionalizaram-se os planos de estudo, incorporando neles as exigências das FFAA que atuavam na OTAN, como o aumento das horas dedicadas às ciências sociais;

6) Adaptação da estrutura educativa militar ao sistema educativo nacional, o que significava aproveitar os centros de ensino civil para complementar o ensino militar e vice-versa.

Pelos pontos indicados, a reforma no ensino militar foi profunda. Porém, como me foi possível compreender pelas entrevistas realizadas, não apenas ela não atingiu seus objetivos - que eram acabar definitivamente com o ensino exclusivamente militar, transformando o adestramento nas técnicas especificamente castrenses em aprendizado complementar -, como apenas se tornou realidade pela capacidade de negociação 
do governo civil somada à exposição das FFAA aos seus congêneres externos. Ainda assim, pudemos perceber o quanto hoje as FFAA são modernas e comungam com os ideais da democracia, entre eles a eqüidade de gênero. Afinal, como não dizer isso de uma organização militar que não apenas se submete à autoridade civil, mas o faz quando quem representa esta autoridade é uma mulher grávida? ${ }^{18}$

Em resumo, o tipo de reforma posto em prática, considerando todo o seu espectro e não apenas relativamente ao ensino, além de exigir que todos os atores compartilhem um objetivo claro, tem alto custo financeiro. É isso que explica o aumento gradativo e considerável do orçamento militar. Sabiase, entretanto, que o aumento nos gastos no presente seria recompensado no futuro, não apenas pela redução do orçamento para a defesa, mas principalmente pela estabilidade e orgulho do povo relativamente às suas FFAA, como de fato hoje se conhece. Por isso, pode-se dizer, sem nenhum perigo de erro, que a transição na Espanha foi um grande sucesso e hoje se vive no país um estado de bem estar social sob a democracia política jamais imaginada na sangrenta história do país.

\section{Palavras finais}

Quem andar pelas ruas da Espanha poderá perceber que a democracia no país está consolidada, porque os cidadãos sentem orgulho de serem espanhóis e sem saudosismos. A despeito da crise que se iniciava ao longo de 2008, diariamente foi possível presenciar sinais de alegria e de compromisso dos cidadãos com o futuro de seu país. Sabem que dias difíceis virão, mas nem por isso perdem a perspectiva de futuro, perda essa tão comum em países de democratização recente, como o Brasil é nosso melhor exemplo.

Não por acaso, a maior exigência para se fazer a reforma foi a vontade política, que foi revelada nas entrevistas e no cotidiano: não há como reconstruir um país e levar suas FFAA a sentirem-se responsáveis por sua defesa, deixando de ser forças 
APONTAMENTOS À ANÁLISE DA REFORMA MILITAR...

de contenção social para forças estritamente profissionais sem que haja consenso sobre o que se quer, mesmo que não haja consenso sobre como chegar ao objetivo. A eleição de caminhos diferentes explica as diferenças entre os governos socialistas e os demais. Tomando apenas a questão militar, quando o PSOE esteve no poder, as reformas foram mais rápidas e profundas. Quando a direita controlava o governo, as reformas foram mais lentas ou sequer existiram.

Desse modo, a construção da democracia, com a necessária transformação militar, não foi fácil, foi recortada por idas e vindas que acompanharam os ventos da política, mas foi profunda e definitiva. Também foi enfatizado nas entrevistas que o sucesso da transição espanhola assentou-se sobre a regra do consenso e a certeza quanto aos objetivos. Foram esses dois pilares que fizeram com que a transição espanhola fosse reconhecida não só como modelo de análise, mas também como exemplo político.

\section{Referências Bibliográficas}

\section{Publicações}

BARRIOS, Raquel Barrios (2006). El Proceso de Transición Democrática de las Fuerzas Armadas Españolas. 1973-1989. Tese Doctoral, UNEDFacultad de Geografía e Historia- Departamento de Historia Contemporánea, 2006, digit.

CANEIRO, José G. (s/d.) I. La transición militar a la democracia en España: la búsqueda de un nuevo soldado democrático, digit.

. II. El Cambio de lo que cambió para que nada cambiase o como sostenella, negocialla y no enmendalla en la enseñanza militar. Digit.

GARCÉS, Joan E. (2008). Soberanos e Intervenidos: Estrategias globales, americanos y españoles. Madri, Siglo XXI Ed., $3^{a}$ Ed. (1a Ed., 1996).

MARAVAlL, J. M. \& SANTAMARÍA, J. (1988). A mudança política na Espanha e perspectivas da democracia. In O'DONNELL, G.; SCHMITTER, P. \& WhiteheAd, L. (eds.) Transições do Regime Autoritário: Sul da Europa. São Paulo, Vértice, 1988 (Tradução de Adail Sobral). 
O'Donnell, G. \& SCHMitTER, P. (1988). Transições do Regime Autoritário: primeiras conclusões. São Paulo, Vértice. (Tradução de Adail Sobral).

PUELl DE LA Villa, Fernando (1997). Gutiérrez Mellado, Un militar del siglo XX (1912-1995). Mdri, Biblioteca Nueva.

SAINT-PIERRE, H. \& MATHIAS, S. K. (2004). A educação militar como variável estratégica. Congresso Internacional da LASA, digit.

SERRA, Narcís (2008). La transición militar: reflexiones en torno a la reforma democrática de las fuerzas armadas. Barcelona, Randon House Mondadori.

SuÁRez PertierRA, Gustavo (2004). Veintecinco años de Constituición y Fuerzas Armadas. In Revista de Derecho Político, nºs. 58-59, PP. 95-116.

\title{
Entrevistas
}

Clemente Herrero Fabregat

Enrique Veja Fernández

Fernando Amerigo Cuervo-Arango

Gustavo Suárez Pertierra

Jesús Ramón Bacas Fernández

José G. Caneiro

José Viegas Filho

Sonia Alda Mejias (conversas informais).

\section{Documentos Oficiais:}

Constituição do Reino da Espanha de 1978.

Legislação. Boletin Oficial de España (BOE), diferentes números, 1975/2008.

MATHIAS, Suzeley Kalil. Notes about military reform in the Spanish transition. História, v.28, n.2, p.733-774, 2009.

\begin{abstract}
In this paper, we revisit the recent Spanish political process, emphasizing issues relating to the Armed Forces (FFAA), trying to understand since the formation of these forces prior to the dictatorship of Francisco Franco, through this and coming to today, when it seems that the reforms promoted over past 30 years, that finally resulted in the Armed Forces incorporated of democracy.
\end{abstract}

Keywords: Democracy; Armed Forces; South America; Government. 
APONTAMENTOS À ANÁLISE DA REFORMA MILITAR...

\section{NOTAS}

${ }^{1}$ Este artigo é, em grande medida, resultado de nossa estada no Instituto Gutiérrez Mellado (Madri), entre março e julho de 2008, com bolsa de pós-doutorado da CAPES, sem a qual seria impossível a realização do trabalho. Agradecemos aos funcionários e acadêmicos do IGM e a todos os que nos concederam entrevistas, em especial à Dra. Sonia Alda Mejias, que se desdobrou para nos auxiliar em nossa investigação. Registramos que todas as afirmações feitas ao longo deste texto são de nossa inteira responsabilidade.

${ }^{2}$ Importante assinalar que a construção do Império Ibérico aconteceu em menos de 200 anos, pois foi por meio do Tratado de Tordesilhas, assinado entre Portugal e Espanha em 1494, que ambos países jogaram-se ao mar. Uma visão interessante a respeito está em Garcés, [1996] 2008.

3 Nas palavras dos planejadores militares norte-americanos, “...Espanha é a área política mais sensível do Mundo..." ([1943] Apud Garcés, 2008: 29)

4 A afirmação de Alda foi: "quê nos restaria depois de anos de fechamento para o mundo senão a África? E como poderíamos nós, espanhóis, aceitar isso sem uma profunda mudança do próprio sentimento de orgulho da identidade européia? Assim, entrar para a União Européia e para a OTAN foi a saída natural da Espanha depois da ditadura". Conversa informal em 06/05/2008.

${ }^{5}$ Definimos extensivamente militarização em trabalho anterior (2004), que tem três sentidos: militarização diz respeito à participação física ou à ocupação de cargos da administração pública civil pelos militares. Neste caso, supõe-se que a administração é um meio de transmitir interesses para todo o sistema político. A apreensão do fenômeno é aqui mais fácil, pois se trata de comparar quantitativamente o peso de cada ator (civil e militar) na burocracia estatal; a impressão ou transferência de valores castrenses para a administração pública também é entendida como militarização. Em outras palavras, o ethos político (ou que vigora na Polis) é equivalente ao ethos militar. Neste caso, a definição é profundamente subjetiva e somente pode ser apreendida indiretamente; militarização pode ser ainda a realização, por meio das políticas governamentais, das doutrinas defendidas ou formuladas pelos militares. Assim, quando uma política segue padrões 
geopolíticos ou responde ao autoritarismo embutido na Doutrina de Segurança Nacional, pode-se dizer que ela realiza um processo de militarização.

${ }^{6}$ Entre abril e julho de 2008, realizamos sete entrevistas e também pudemos participar de várias conversas informais com personalidades universitárias, membros do governo e militares. Considerando a totalidade dessas oportunidades, apenas uma pessoa divergiu desta avaliação.

${ }^{7}$ O papel desempenhado por Diez Alegria ainda está para ser escrito e, mesmo existindo diferentes trabalhos sobre Gutiérrez Mellado, estes pouco destacam a relação entre ambos ou destacam a importância deste na questão de reformas que vão além da criação do Ministério da Defesa. Infelizmente, aqui não temos espaço suficiente para tanto. Registramos, porém, que todos aqueles que participaram do processo de reformas ou o analisaram, que foram por nós entrevistados, insistiram em sublinhar a importância fundamental de ambos na transição, em especial de seu componente militar.

8 Franco jamais permitiu a organização de partidos políticos, argumentando que eles desenvolviam a divisão na sociedade civil e impediam, assim, a paz social. No entanto, permitiu o aparecimento de diversas associações civis que passaram a funcionar como entidades partidárias. Este é o caso do (Partido) Movimento Nacional, que reunia aqueles que apoiavam abertamente o regime e mesmo os que defendiam opções políticas mais reacionárias que a própria ditadura franquista.

9 A Coordinación Democratica (CD) reunia boa parte da oposição, congregando grupos de centro (democratas-cristãos e liberais) até comunistas, maoístas e sindicalistas cassados.

10 Transição é o substitutivo do verbo transitar, que é definido na língua portuguesa como verbo transitivo direto e indireto, isto é, independente da sua forma no texto, sempre pedirá um complemento que indicará ou o processo - transitar no sentido de 'seguir por este ou aquele curso' -, ou a origem e objetivo - transitar no sentido de 'ir de um determinado lugar para outro diferente do primeiro -, do evento ou sujeito. Tendo este significado aqui especificado, eximimo-nos de adjetivá-lo a todo momento. Quando utilizarmos o termo transição, estaremos sempre nos referindo àquele momento que se localiza entre o final da ditadura e a estabilização das regras em torno do novo regime político. No caso específico, dado que a análise objetiva 
APONTAMENTOS À ANÁLISE DA REFORMA MILITAR...

acompanhar a reforma militar, datamos o período de transição entre 1975, com a proclamação de Juan Carlos como chefe de Estado, e 1982, representado pelas eleições, quando o governo passou a dirigir de direito e de fato as iniciativas quanto às FFAA. Também o ex-ministro da Defesa, Narcís Serra, defende esta datação.

${ }^{11}$ Os resultados eleitorais foram os seguintes: UCD $=35 \%$ dos votos válidos; PSOE $=29,4 \%$; PSB $=4,5 \%$ (portanto, os socialistas obtiveram $34,8 \%$ dos votos válidos); $\mathrm{PCE}=9,3 \%$ e Aliança Popular (AP, o partido que representava o franquismo) $=8,5 \%$. O restante dos votos foram divididos entre pequenos partidos, incluindo a extrema direita e a extrema esquerda. (Maravall \& Santamaria, op. cit.: 129)

${ }^{12}$ Aqui não é o lugar para discutir esses Pactos, pois os acordos não envolviam diretamente a questão militar. Trataram, basicamente, da questão econômica, permitindo um certo fôlego para o governo e uma certa tranqüilidade para os demais setores objetivando criar as condições para o funcionamento da Assembléia Constituinte. Os acordos feitos ganharam o nome de Pactos de la Moncloa porque foram feitos no Palácio de mesmo nome e que é sede do governo espanhol.

${ }^{13}$ Gutiérrez Mellado apenas se afastou do MD, mas manteve a Primeira Vice-Presidência para Assuntos de Segurança e Defesa Nacional.

14 As bases normativas para esta reforma foram: Real Decreto 2223/1984; 288/1997; Real Decreto 207/2003; Lei 46/1985 e Lei 17/1989.

${ }^{15}$ Entrevistas realizadas em 10/06/2008 e 04/07/2008.

${ }^{16}$ Quando publicada a lei (Real Decreto 1000/85), acreditava-se que apenas o Exército estava inchado, com um número muito além do necessário para cumprir suas missões. Entretanto, pouco depois, notou-se que as demais Forças, ainda que em menor escala, também tinham excesso de pessoal. Constatada a necessidade de redução do contingente de todas as Forças, a reserva transitória foi estendida à Marinha e Força Aérea.

${ }^{17}$ Registramos que em duas das entrevistas que realizamos, uma das quais com um dos responsáveis diretos das reformas na educação militar, não se escondeu a desilusão pela falta de continuidade nesta política ao longo do governo dirigido por José Maria Aiznar, do PP (1996-2004). Mesmo tendo passado 4 anos do governo de José Luiz Zapatero (desde março de 2004), os mesmos interlocutores ainda mostravam alguma esperança na retomada das reformas no ensino.

${ }^{18}$ Em seu Segundo período de governo, Zapatero nomeou, em abril de 2008, a jovem (37 anos) deputada pela Catalunha, Carmen Chacón, 
grávida de 7 meses, para assumir a Pasta da Defesa. A despeito do alarde que se fez na imprensa, com entrevistas e reportagens diárias sobre o "estado" da ministra, não houve nenhum comentário vindo da caserna, mesmo de setores já reformados, a respeito do assunto. Passado um mês, antes mesmo de dar à luz ao seu primeiro filho, Chacón já havia conquistado a todos, provando, uma vez mais, que a transição política espanhola realmente forjou mais que um regime, uma sociedade democrática. Para uma panorâmica sobre os primeiros meses de gestão da Ministra, consulte-se o diário El Pais, principalmente entre abril e julho de 2008.

Artigo recebido em 08/2009. Aprovado em 11/2009. 